\title{
PRAXIS OF THE SOVIET AVANT-GARDE
}

LEAH HASDAN

$I^{\prime}$ $\mathrm{n}$ the Dialectic of Enlightenment, Max Horkheimer and Theodor Adorno discuss how the culture industry is backed by a noncommittal vagueness of ideology, which, in turn, influences the production of art. Horkheimer and Adorno argue that, like the culture industry ${ }^{1}$, art is bound to its struggle with tradition and is unable to transcend a new reality-or give way to a new cultural identity. The authors look towards autonomous art, recognized in the presentation of the avant-garde, to transcend the milieu of the culture industry. Yet, as they argue, "the claims of art are always also ideology" midst of society's attempting to sever itself from tradition (in hopes of striving for a new identity), avant-garde art does not transcend reality, for it is nonetheless backed by the instrumentalization of ideology and places the artist's identity into crisis.

Art is understood as the presentation of truth claims that reveal the current condition of the social order. Horkheimer and Adorno argue that art is able to transcend reality when it breaks from its tradition or its style; however, style is shaped by tradition,

1 "The culture industry has abolished the rubbish of former times by imposing its own perfection, by prohibiting and domesticating dilettantism, while itself incessantly commiting the blunders without which the elevated style cannot be conceived" Adorno, Theodor W, Max Horkheimer, and Gunzelin Schmid Noerr. 2009. Dialectic Of Enlightenment. 1st ed. Stanford, Calif: Stanford Univ. Press. 108.

2 Adorno, Theodor W, Max Horkheimer, and Gunzelin Schmid Noerr. 2009. Dialectic Of Enlightenment. 1st ed. Stanford, Calif: Stanford Univ. Press. 103. 
and a work of art can only break from its tradition when it has developed a new style. In order for a work of art to develop a new style - to break from tradition and transcend reality - it must expose itself to the failures of culture. Yet, if a work of art does not expose itself to the "necessary failure of the passionate striving for identity" that marks the discrepancy between tradition and style, then the work of art reverts to immanence, relying on its similarity to others, which marks, for Horkheimer and Adorno, the "surrogate of identity." If art fails to diverge ${ }^{3}$ from its style, then it submits to the "obedience of the social hierarchy." 4

If art is the presentation of truth claims that expose the condition of the social order, then it is always ideology if it does not contest the social hierarchy. Therefore, good art, determined by "what the Expressionists and Dadaists attacked in their polemics, the untruth of style as such," is that which contests its own cultural identity. In order for art to challenge its identity, or break from its tradition, it calls for artists to develop their own style. The greatest artists, then, according to Horkheimer and Adorno, are "those who adopted style as a rigor to set against the chaotic expression of suffering, as a negative truth." " A good artist is one who indirectly communicates suffering by means of inducing a pleasurable, moving experience. An artist with good style indirectly develops his style by means of contesting the guise, absence, or lack of presentation, of suffering. Therefore, in the realization of his style, developed out of the artwork itself, the artist does not obey the social hierarchy, but always challenges its claim to truth.

In this notion, we recognize revolution. The Soviet Avant-Garde movement is one of the best examples of artists' demanding a change in the social hierarchy and producing work that embodies the experience of suffering. The newly revolutionized Soviet state, however, invariantly politicized the artistic Avant-Garde movement of its time: it enforced the ideology of the revolution - through a scientific method of organization at its forefront-where the venerated reality of the revolution remained trapped by the instrumentalization of its own ideology. For the Constructivist movement in particular, this meant abandoning all a priori conceptions and iconographical elements to investigate the metaphysical contradiction between building materials.

The Constructivists sought harmony in the least amount of excess necessary for construction. Perhaps this is best recognized in Aleksandr Rodchenko's Oval Hanging Construction No. 12 (1920), which was constructed out of a single sheet of plywood. This deductive structure was then coated with aluminum, cut into various

3 Although the authors use "divulge" in the initial text to argue that the culture industry exposes style as conformity, "[the culture industry] being nothing other than style, it divulges style's secret: obedience to the social hierarchy," they are really stressing that style must break from culture if art is to transcend reality (Adorno, Horkheimer and Schmid Noerr 2009).

4 Adorno, Theodor W, Max Horkheimer, and Gunzelin Schmid Noerr. 2009. Dialectic Of Enlightenment. 1st ed. Stanford, Calif: Stanford Univ. Press.103-104.

5 Adorno, Horkheimer and Schmid Noerr 2009

6 Adorno, Horkheimer and Schmid Noerr 2009 
concentric geometric shapes, and positioned in such a manner to form a geometric three-dimensional volume that would plicate into its original planar condition. The Oval Hanging Construction demonstrated a pedagogical directness by showcasing its bare process of production. This method of construction implements a dialectical approach to the integrity of the materials by posing a contradiction to the identity of the transient art object: the construction, or the art object, therefore operates as a motivated sign, whereby its composition is arbitrarily limited by its relationship to its materials. Whereas a composition is merely arbitrary, the Constructivist's art objects are motivated by its integrity of material, and by the least amount of excess necessary for its construction. ${ }^{7}$

Operating as a motivated sign, the constructions ultimately stress the discontinuities in temporal and spatial elements of experience, also introducing the artist's work as an intervention towards the social practice of mass cultural representation. ${ }^{8}$ Yet, this intervention of mass cultural representation is precisely what is at stake here. The Constructivist's pedagogical directness did not contest mass cultural representation; rather, they used it as a means to re-constitute a collective identity. Mediating the transcendence of a new identity by embodying the power of mass cultural representation, the Constructivists dismissed the authentic experience of the viewer, which establishes the validity of the art object. The Constructivist's logical method of production induces an absence or loss of experience for the viewer, such that the artist imposes a manufactured reality onto the art object-leaving no room for the viewer to authentically reflect and establish a connection to the art object.

The loss of experience, according to Adorno, occurs when ideology or preconceived, a priori concepts mediate the essential moment of objectivity. The essential moment of objectivity occurs when the object or thing-in-itself is not falsified by mediated concepts; the object must be experienced for what it is as intention recta ${ }^{9}$, and must "prove itself in that it qualitatively alters the opinions of reified consciousness." 10 The viewer's loss of experience is recognized in the Oval Hanging Construction's discontinuities in temporal and spatial elements of experience. The Oval Hanging Construction denies the possibility of an essential moment of objectivity because it cannot disentangle its temporal and spatial elements of experience from the ideological framework in which its very form and materiality are constituted. Therefore, the Oval Hanging Construction cannot be considered a thing-in-itself outside of its ideological framework. As such, the Oval Hanging Construction is arbitrarily limited as a motivated sign. In its demonstration of the least amount of

7 Foster, Hal. Art since 1900: Modernism, Antimodernism, Postmodernism. 2nd ed. Vol. 184.

8 Foster, Hal. Art since 1900: Modernism, Antimodernism, Postmodernism. 2nd ed. Vol. 1. New York: Thames \& Hudson, 2004. Print. 183.

9 The state of consciousness which focuses upon the true object, rather than on an image of the object within the intellect.

10 Adorno, Theodor Wiesengrund, Henry W Pickford, and Lydia Goehr. 1998. Critical Models. 1st ed. New York: Columbia University Press. 252. 
excess of materials, the Oval Hanging Construction holds captive the experiential reality of production by staying true to its representation of efficiency. The viewer's experience of the deductive materiality in the Oval Hanging Construction is entirely mediated by the motivation - the interjection of ideology on behalf of the artist. Presenting its ability to be reverted into its original planar condition, the thing-initself is robbed of its essential moment of objectivity, for it is only suggestive of a fixed manufactured experience and cannot be recognized as such—as its true object. Yet what guides the residual notion of objectivity it not necessarily the thing-in-itself, but rather something man-made entirely:

[I] $\mathrm{t}$ is the model of the profit that remains on the balance sheet after all production costs have been deducted. Profit, however, is subjective interest limited and reduced to the form of calculation. What counts for the sober matter-of-factness of profit thinking is anything but the matter: it disappears into the return it yields. ${ }^{11}$

The subjective viewer's interest towards the art object reflects what is common to the community and its forms of visibility, thereby marking the residual notion of objectivity within the capitalist framework. The basic level of production suggests that subjective interest does not recite quantifiable value, whereas in a heightened sense of production (induced by the capitalism system), subjective interest obtains a relationship to the quantifiable value of the profit-gain return model.

The quantifiable abstract value inherent to capitalism demands the subject to regard the world with an interest that is fundamentally quantitative. Something may be valued, such as the Oval Hanging Construction, the viewer's experience is in fact mediated by the capitalist profit-thinking: fundamentally quantitative mentality. It is not so much that the viewer looks towards the art object as a literal form of quantifiable value; rather, it is that the viewer enters an organized method of social programming - that of the capitalist regime-where he forfeits the spontaneity of his or her own contemplation for the sake of a quantifiable, tangible operation of contemplation where "ideology [...] makes life initially easier for the spectators." 12

In the same sense that the art object is trapped by the predetermined framework of its own ideology, the experience of the art object as such is set up in advance to determine the viewer's experiences as nothing but the culture industry's object, which is to view the art object as a cyclical invariant of the production. ${ }^{13}$ In this sense, the loss of experience is predicated on the notion of "the ideal of depersonalizing knowledge

11 Adorno, Theodor Wiesengrund, Henry W Pickford, and Lydia Goehr. 1998. Critical Models. 1st ed. New York: Columbia University Press. 253.

12 Adorno, Theodor W, Max Horkheimer, and Gunzelin Schmid Noerr. 2009. Dialectic Of Enlightenment. 1st ed. Stanford, Calif: Stanford Univ. Press. 117.

13 Adorno, Theodor W, Max Horkheimer, and Gunzelin Schmid Noerr. 2009. Dialectic Of Enlightenment. 1st ed. Stanford, Calif: Stanford Univ. Press. 113. 
for the sake of objectivity." ${ }^{14}$ The loss of experience occurs when ideology determines thinking for us. When the essential moment of objectivity for the construction falls prey to mediated a priori concepts, the separation between theory and praxis emerges in the loss of experience and knowledge.

Perhaps the Constructivists developed a new style at best. If reinforcing ideology by giving it aesthetic form can been regarded as style, then their art objects alluded to the idealized transparency of the political state. It is clear that Rodchenko's Oval Hanging Construction presents theory in operation: his construction lays bare the process of production and calls the experience of efficiency into question for the viewer. However, if thinking is a form of doing; and theory is a form of praxis, ${ }^{15}$ then is the articulation of theory successful here?

Both the art object and the viewer exist within a revolutionary moment of passionate striving for a new cultural identity. If the construction is a motivated sign, does the Oval Hanging Construction confront challenges of production? The failure to do so strikes the revolutionary moment as incomplete, for the viewer enters the artistic space in search for a direction, anticipating an answer to the revolutionary call. Yet the viewer operates under the profit-thinking model that renders them docile, forfeiting the spontaneity of their own contemplation for the ideology presented before them. The articulation of theory is quite relevant here, for if the viewer is confronted with a ready-made cliché defined by the cultural schema within which it operates, then to what extent does cliché answer the revolutionary call by suspending a sense of reflection within the viewer? Does theory carry out its goal in the Oval Hanging Construction if the construction reinforces the hierarchical representation of production rather than posit a form of alterity?

The Constructivists' pedagogical directness demonstrates a loss of experience that is necessary to prologue the revolutionary fervor for both artist and viewer. The revolutionary experience sparks the guiding ideology of the revolution is extinguished when every phase of artistic production and choice of material is planned. This loss of revolutionary experience isolates theory from its praxis by collapsing the distinction between the artwork and its message:

What since then has been called the problem of praxis and today culminates in the question of the relation between theory and praxis coincides with the loss of experience caused by the rationality of the eternally same. Where experience is blocked or altogether absent, praxis is damaged and therefore longed for, distorted, and desperately overvalued. Thus what is called the

14 Adorno, Theodor Wiesengrund, Henry W Pickford, and Lydia Goehr. 1998. Critical Models. 1st ed. New York: Columbia University Press. 253.

15 "A consciousness of theory and praxis must be produced that neither divides the two such that theory becomes powerless and praxis becomes arbitrary [...] thinking is a doing, theory a form of praxis." Adorno, Theodor Wiesengrund, Henry W Pickford, and Lydia Goehr. 1998. Critical Models. 1st ed. New York: Columbia University Press. 261. 
problem of praxis is interwoven with the problem of knowledge. Abstract subjectivity, in which the process of rationalization terminates, strictly speaking can do just as little as the transcendental subject can conceivably have precisely what it is attested to have: spontaneity. ${ }^{16}$

What induces the artist's disconnect from the spontaneity of the revolutionary experience is his preconceived commitment to the artistic material, precisely because the construction is a motivated sign, where the form of the art object communicates a truth limited in its interpretation. The art objects obey the social hierarchy by presenting truth claims that have been manufactured by the politicization of the state.

The separation of theory from praxis is most evident in Vladimir Tatlin's Monument to the Third International (1920). Originally crafted in wood within a scale of 18 to 22 feet, the finished monument was intended to be a 1300-foot metal-and-glass sculpture (which, at the time, would have surpassed the world's tallest building [the Eiffel Tower] by one third) that aimed to embody the new ethos of the Revolution. Tatlin's celebrated design consisted in two dovetailing conical spirals contained within a web of oblique and vertical slats, which framed four geometric glass volumes stacked on top of each other within the structure's slanted core.

The four glass volumes were intended to rotate at specific paces-each representing a branch of the Comintern, or the Soviet organization in charge of spreading the revolution abroad. The revolution regarded with the slowest pace was the largest volume, symbolizing the International's "legislative assemblies," intended to rotate for the length of a year. The second volume would house the executive branch and rotate for a month; the next volume, the propaganda services, would take a day; the uppermost volume was added as a late edition to the project and would have presumably lasted an hour. ${ }^{17}$

A construction built off of the cyclical rigid invariants developed out of the social disorder of the revolution, Tatlin's art object presents a harmony that was guaranteed in advance. Intended to rebel against the cultural complacency left over from the monarchical tradition, the material form of Tatlin's construction quite literally obeys its own hierarchy in the new Soviet order. Although there were several arguments made in favor of the production, Tatlin's design was never realized. He failed to justify his formal use of a spiral, and its appeal to an age-old iconography, reducing his construction to a cultural, traditional invariant of the same. The Working Group of Objective Analysis, established by Rodchenko, regarded Tatlin's monument as a fetishization of artistic production - a romantic affair: "by a lone artist in the secrecy of his studio and with the traditional tools of his craft; its formal organization

16 Adorno, Theodor Wiesengrund, Henry W Pickford, and Lydia Goehr. 1998. Critical Models. 1st ed. New York: Columbia University Press. 260.

17 Foster et. al 2004 p.183 
remained an indecipherable secret that reeked of 'bourgeois individualism': it was not a construction but an authorial composition." 18

Through his logical method of production, Tatlin isolated himself, as well as his work, from the Constructivist community precisely because he was detached from the theory of the revolutionary fervor. The unembroidered material representation of the Soviet social hierarchy in the Monument to the Third International destroys any opportunity for the essential moment of objectivity because the construct cannot be viewed as anything other than its literal representation. The absence of spontaneity in Tatlin's artistic processes, the concrete memorialization of a suffering void of actually inducing a moving, reflective experience for the viewer, demonstrates his inability to articulate theory and therefore isolates praxis altogether.

The absence — or loss — of an experience that may stimulate reflection and generate knowledge, rooted in the complacency of profit-thinking, constitutes the artist's failure to incite an authentic connection with his work: "the lack of self-reflection [...] is the mark of a praxis that, having become its own fetish, becomes a barricade to its own goal." ${ }^{19}$ In the attempt to respond to the call of the revolutionary fervorto strive for a new cultural identity-the Constructivist movement organized its revolutionary theory within the efficiency of production. Initially emerging out of the platform of autonomous art, the Constructivist movement should have challenged itself, contested the social order, and promoted a social alterity. Since it failed to stay true to its roots, it did not produce works of art that challenged themselves or instigated spontaneous reflection necessary to carry out its own goal. The art object should not answer a call to what should be done, but present an aesthetic experience that gives space for critique.

Though the Constructivist movement did not succeed in its autonomous intent, such failure does not exist because of theory's failure to prescribe praxis. The distinction between theory and praxis does not suggest a temporal continuity: "the relationship between theory and practice after both have once distanced themselves from each other is that of qualitative reversal, not transition, and surely not subordination." ${ }^{20}$ The disenchantment of the Constructivist movement is due to the loss of identity on behalf of the artist. Trapped by the constraints of ideology, the Soviet Avant-Garde artist did not successfully critique his tradition, and therefore lacked a presentation of style such that it ultimately failed to induce an aesthetic experience that would promote the passionate striving for an alterity, or a new cultural identity.

18 Foster, Hal. Art since 1900: Modernism, Antimodernism, Postmodernism. 2nd ed. Vol. 1. New York: Thames \& Hudson, 2004. Print. 182.

19 Adorno, Theodor Wiesengrund, Henry W Pickford, and Lydia Goehr. 1998. Critical Models. 1st ed. New York: Columbia University Press. 262.

20 Adorno, Theodor Wiesengrund, Henry W Pickford, and Lydia Goehr. 1998. Critical Models. 1st ed. New York: Columbia University Press. 277. 
Theodor Adorno specifies that successful action arises out of engaging in the art of critique. Addressing the oscillation between theory and praxis yields the spontaneity of imagination, which presents the possibility for change. In this respect, Adorno believes that art should be autonomous. Insofar as art compels change through the dialectical approach of critique, "art is the critique of praxis as unfreedom; this is where the truth begins." ${ }^{21}$ Moreover, Adorno mentions that praxis embodies a sincere and intense conviction, which is broken when praxis liberates itself out from the interplay between the sensuous and the rational movements of the intellect, which are expressed in Friedrich Schiller's play drive. ${ }^{22}$

It is true, nonetheless, that $S$ chiller proposes if man were to achieve change successfully, then "he will have to approach it through the problem of the aesthetic, because it is only through beauty that man makes his way to freedom." ${ }^{23}$ In order for theory and praxis to succeed - for the interplay between the sensuous and rational to remain in balance - the artist must induce an aesthetic experience, which would stimulate the inherent reflection - the spontaneity of imagination necessary for change. Because the free play of the imagination mimics the intellect's capacity to conceive of a political alterity, Schiller calls for a historically situated intellectual reflection.

This is what makes Schiller's system attractive to Adorno: the fact that Schiller diagnoses his historical moment, and attributes its corrective task to an aesthetic experience, incites freedom's capacity to keep itself in check through the active interplay of the imagination. The dialectical procedure of the aesthetic experience, developed out of the sensual, instigates the imagination to posit an alterity that may then be grounded and articulated in a reasonable local manner that tailors the current condition of the social order. Schiller's system offers a similar operation of theory and praxis in the sense that freedom induced by reflection is not removed from its actual practice: rather, it opens up a space to critique, to preserve intention, and to give way to a proper form of practical freedom.

What remains of interest here is that Schiller emphasizes a critique of the historical moment, where his response to the revolutionary call stands in accordance with an aesthetic self-reflection, and where the viewer is able to generate knowledge and earnestly partake in a form of praxis. In respect to Soviet Avant-Garde art, praxis was isolated from theory when the artist produced constructions that preserved the Soviet identity by trapping representation in material form, as opposed to producing works of art aimed at inciting spontaneous reflection-which would develop a space for critique and the production of knowledge.

21 Adorno, Theodor Wiesengrund, Henry W Pickford, and Lydia Goehr. 1998. Critical Models. 1st ed. New York: Columbia University Press. 262.

22 Adorno, Theodor Wiesengrund, Henry W Pickford, and Lydia Goehr. 1998. Critical Models. 1st ed. New York: Columbia University Press. 262.

23 Schiller, Friedrich von, Walter Hinderer, and Daniel O Dahlstrom. 2005. Essays. New York: Continuum. 90. 
It is as if the Soviet artist conceived of himself as a mere agent of ideology, solving the historical moment through its preservation, executed via efficient assembly. What is there to be said about the lack of self-reflection, perhaps on the part of the artist, in the ever-changing contextual moment? We may come to recognize that the transparency of the artist's pedagogical directness reveals a silencing on the artist's part-sacrificing the identity of his own narrative to present the logic of collective assembly. Yet, in the historical moment of striving for a new identity, the logical method of organization lays bare the complacency of profit-thinking where the artist is only valued based on the efficiency of his assembly. The Soviet artist cannot but help face isolation as he anticipates losing true value in his commitment to rigid ideology:

....in the eyes of those who nourished the all too abstract and illusory hope for a total transformation might have appeared justified-that is, violence-after the experience of the National Socialist and Stalinist atrocities and in the face of the longevity of totalitarian repression is inextricably imbricated in what needs to be transformed [...] Whoever does not make the transition to irrational and brutal violence sees himself forced into the vicinity of the reformism that for its part shares the guilt for perpetuation the deplorable totality [...] Dialectic is perverted into sophistry as soon as it focuses pragmatically on the next step, beyond which the knowledge of the totality has long since moved. ${ }^{24}$

Although the Constructivist movement may be read as a call for order in the lingering moment of revolutionary fervor, the crisp delineation of geometric lines erects borders around empty space, which operate as mere frames that hug an unknown, undefined territory. If the art objects of the Constructivist movement were to bear meaning outside of their initial ideology, they would be seen as memorials to the insecure struggle, and collective loss of identity. In his logical presentation of material, the Soviet artist bears witness to the violent nihilism of constructing value out of mechanical assembly.

Insofar as theory is a form of praxis ("if thinking bears on anything of importance, then it initiates a practical impulse, no matter how hidden that impulse may remain to thinking" ${ }^{25}$ ), then the artistic vision and its aesthetic experience are also productive. Schiller believes that the practical impulse in the artistic process depends on the artist's handling of the subject matter-specifically that the artist obtains the power to manipulate form so that it may destroy and consume material. The more seductive the material appears in itself, "the more it seeks to impose itself upon us, the more high-handedly it thrusts itself forward with effects of its own." 26 Artistic production, according to Schiller, carries with it the capacity to transform, destroy,

24 Adorno, Theodor Wiesengrund, Henry W Pickford, and Lydia Goehr. 1998. Critical Models. 1st ed. New York: Columbia University Press. 268.

25 Adorno, Theodor Wiesengrund, Henry W Pickford, and Lydia Goehr. 1998. Critical Models. 1st ed. New York: Columbia University Press. 264.

26 Schiller, Friedrich von, Walter Hinderer, and Daniel O Dahlstrom. 2005. Essays. New York: Continuum.151. 
and give shape to materials based on our susceptibility to its sensuousness. This process of production is precisely how The Working Group of Objective Analysis constituted Tatlin's romantic affair in the secrecy of his own studio: "in contrast with the bourgeois artist's studio secrets, the sculpture's 'logical' mode of production and deductive structure where heralded as a means of opposing the fetishization of artistic production." ${ }^{27}$

However, the logical mode of production lacks the susceptibility to sensuous materiality present in Schiller's system, and the aesthetic experience altogether. The material appears sensuous through artistic production: the artist realizes his artistic vision through the process of destroying material—of giving it form. Through this process of creation, the art object appears sensual because it serves as a vestige of this artistic consciousness. The viewer seduced by the sensuousness of material because artistic production has rendered it as a presentation of the artists' consciousness: the material now embodies an inductive experience that validates the existential existence of the viewer.

It is the viewer's experience of recognizing the power of the gaze that reflects the violence of artistic production back to itself. The viewer is receptive to the art object's raw material. With the power of the art object's gaze, the viewer must destroy its aesthetic organization, for reflection causes the viewer to examine and dissect forms of detail, dismantling the visual. However, Adorno mentions that the Soviet artist, through his violence-in enforcing the pragmatic direction of reformism and in moments where Constructivist art merely reverts to industry of pedagogical directness - creates an impositional alterity that severs their art from its autonomous roots. A manufactured experience that links alterity with a dependency on ideology, "a work of art, which expresses intelligence more than anything else, can never strike us as noble, any more than it is beautiful, since it emphasizes a relation of dependence (which is inseparable from purposefulness) instead of concealing it." ${ }^{28}$

27 Foster, Hal. Art since 1900: Modernism, Antimodernism, Postmodernism. 2nd ed. Vol. 1. New York: Thames \& Hudson, 2004. Print. 184.

28 Schiller, Friedrich von, Walter Hinderer, and Daniel O Dahlstrom. 2005. Essays. New York: Continuum. 155. 


\section{BIBLIOGRAPHY}

Adorno, Theodor W, Max Horkheimer, and Gunzelin Schmid Noerr. 2009. Dialectic Of Enlightenment. 1st ed. Stanford, Calif: Stanford Univ. Press.

Adorno, Theodor Wiesengrund, Henry W Pickford, and Lydia Goehr. 1998. Critical Models. 1st ed. New York: Columbia University Press.

Foster, Hal. Art since 1900: Modernism, Antimodernism, Postmodernism. 2nd ed. Vol. 1. New York: Thames \& Hudson, 2004. Print.

Schiller, Friedrich von, Walter Hinderer, and Daniel O Dahlstrom. 2005. Essays. New York: Continuum. 